\title{
PENTINGNYA PERAN ORANG TUA DALAM PENDIDIKAN KARAKTER ANAK USIA SEKOLAH DASAR
}

\author{
Oleh \\ Ni Kadek Santya Pratiwi \\ Yayasan Pengembang Anak Indonesia \\ kyoo84@yahoo.com
}

\begin{abstract}
Abstrak
Tujuan penelitian ini untuk mengidentifikasi peranan orang tua dalam pembentukan karakter anak, cara membangun karakter anak, pendekatan yang digunakan, hambatan-hambatan dan juga upaya-upaya yang dilakukan dalam pembentukan karakter anak.

Metode yang digunakan dalam penelitian ini adalah metode deskriptif. Hasil penelitian menunjukkan bahwa keluarga adalah faktor penting dalam pendidikan seorang anak. Karakter seorang anak berasal dari keluarga. Dimana, sebagian besar anak-anak sampai usia 18 tahun menghabiskan waktunya $60-80 \%$ bersama keluarga. Sampai usia 18 tahun, mereka masih membutuhkan orangtua dan kehangatan dalam keluarga. Dari sini, sudah sepatutnya pendidikan karakter dimulai dari dalam keluarga, yang merupakan lingkungan pertama bagi pertumbuhan karakter anak. Setelah keluarga, di dunia pendidikan karakter ini sudah harus menjadi ajaran wajib sejak sekolah dasar. Anak SD masih dalam tahap perkembangan operasional konkret. Tahap dimana mulai berkembangnya kecerdasan mereka untuk berpikir logis dan sistematis. Sehingga pendidikan karakter pada anak SD menjadi kunci dalam perubahan generasi muda yang lebih baik.
\end{abstract}

\section{Kata Kunci: Pendidikan Karakter; Pendidikan Dasar; Peran Orang Tua}

\section{A. Pendahuluan}

Pusat pendidikan yang pertama adalah lingkungan keluarga, pendidikan di lingkungan keluarga sangat strategis untuk memberikan pendidikan ke arah kecerdasan, budi pekerti atau kepribadian serta persiapan hidup di masyarakat. Orang tua akan menjadi contoh bagi anak, anak biasanya akan menirukan apa saja yang dilakukan oleh orang tua. Orang tua sebaiknya memperhatikan pendidikan anakanaknya karena peran orang tua sangat penting dalam proses pendidikan bagi mereka. Jadi orang tua harus bisa memberikan keteladanan dan kebiasaan yang baik itu sejak dari kecil atau kanak-kanak karena hal itu dapat berpengaruh terhadap perkembangan jiwa anak.

Pentingnya orang tua terhadap pendidikan anak bukanlah hal yang sepele karena pendidikan adalah modal utama yang harus dimiliki setiap individu yang hidup agar dapat bertahan menghadapi perkembangan zaman.. seperti saat ini orang tua semakin menyadari pentingnya memberikan pendidikan yang terbaik kepada anak-anak mereka sejak dini. Keterlibatan orang tua dalam pendidikan anak-anak terbukti memberikan banyak dampak positif bagi anak. Peran aktif orang tua tentu saja perlu didukung oleh komunikasi yang baik antara orang tua dan juga pihak sekolah. Jadi tidak 
hanya peran guru dan lingkungan yang penting tetapi peran orang tua juga memegang peranan yang sangat penting dalam prestasi belajar anak.

Dewasa ini, banyak kita lihat kenakalan-kenakalan remaja banyak terjadi di lingkungan kita. Bukan hanya di lingkungan sekolah, tetapi juga di lingkungan masyarakat. Anak merupakan anugerah tuhan yang paling berharga yang sudah seharusnya dijaga, diperhatikan dan juga dididik. Semua orang tua pastinya menginginkan anaknya menjadi pribadi yang baik, disiplin, dewasa dan juga tumbuh menjadi pribadi yang memiliki tanggung jawab di dalam hidupnya. Lalu jika saat sekarang ini banyak terjadi peristiwa yang diakibatkan karena kenakalan remaja di sekolah ataupun di masyarakat itu menjadi salah siapa? Kesalahan orang tua dalam mendidik anak atau kesalahan pergaulan yang mengakibatkan anak menjadi liar dan juga susah diatur. Siapapun tidak ada yang bisa disalahkan dalam rusaknya moral anak. Semua orang tua menginginkan anaknya menjadi seseorang yang memiliki kepribadian baik. Untuk itulah peran orang tua sangat penting di dalam tumbuh kembang anak dari anak usia dini hingga anak sudah tumbuh menjadi pribadi yang dewasa.

Pencanangan pendidikan karakter tentunya dimaksudkan untuk menjadi salah satu jawaban terhadap beragam persoalan bangsa yang saat ini banyak dilihat, didengar, dan dirasakan, yang mana banyak persoalan muncul yang di indentifikasi bersumber dari gagalnya pendidikan. Membentuk siswa yang berkarakter bukan suatu upaya mudah dan cepat. Hal tersebut memerlukan upaya terus menerus dan refleksi mendalam untuk membuat rentetan keputusan moral yang harus ditindak lanjuti dengan aksi nyata, sehingga menjadi hal yang praktis dan reflektif. Diperlukan sejumlah waktu untuk membuat semua itu menjadi kebiasaan dan membentuk watak atau tabiat seseorang.

Di sisi lain, pendidikan karakter merupakan upaya yang harus melibatkan semua kepentingan dalam pendidikan, baik pihak keluarga, sekolah, lingkungan sekolah, dan juga masyarakat luas. Pembentukan dan pendidikan karakter tidak akan berhasil jika antara lingkungan pendidikan tidak ada kesinambungan dan keharmonisan. Langkah awal yang perlu dilakukan adalah membangun kembali kemitraan dan jejaring pendidikan yang kelihatannya mulai terputus antara lingkungan sekolah yaitu guru, lingkungan keluarga, dan masyarakat.

Dengan demikian, rumah tangga dan keluarga sebagai lingkungan pembentukan dan pendidikan karakter pertama dan utama harus lebih diberdayakan yang kemudian didukung oleh lingkungan dan kondisi pembelajaran di sekolah yang memperkuat proses pembentukan tersebut.

Banyak hal yang dapat dilakukan untuk merealisasikan pendidikan karakter di sekolah. Konsep karakter tidak cukup dijadikan sebagai suatu poin dalam silabus dan rencana pelaksanaan pembelajaran di sekolah, namun harus lebih dari itu, dijalankan dan dipraktekkan.

\section{B. Metode Penelitian}

Metode yang digunakan dalam penelitian ini adalah metode 
deskriptif. Metode ini dipilih karena masalah yang sedang dikaji adalah menyangkut hal yang sedang berlangsung dalam masyarakat. Dalam hal ini yaitu tentang pentingnya peranan orang tua dalam pendidikan karakter anak usia sekolah dasar.

\section{Hasil Penelitian dan Pembahasan \\ 1. Pengertian Karakter dan Pendidikan Karakter}

Karakter adalah watak, sifat, akhlak ataupun kepribadian yang membedakan seorang individu dengan individu lainnya. Atau karakter dapat dikatakan juga sebagai keadaan yang sebenarnya dari dalam diri seorang individu yang membedakan dirinya dengan individu yang lain. Pendidikan karakter merupakan suatu sistem yang menanamkan nilai-nilai karakter kepada seorang individu yang meliputi ilmu pengetahuan, kesadaran kemauan dan tindakan untuk dapat melaksanakan nilai-nilai tersebut baik terhadap Tuhan YME, dirinya sendiri, orang lain, lingkungannya maupun bangsa dan negaranya.

Pendidikan karakter juga merupakan suatu konsep dasar yang diterapkan ke dalam pemikiran seseorang untuk menjadikan akhlak jasmani dan rohani maupun budi pekerti agar lebih berarti dari sebelumnya. Pendidikan karakter haruslah diterapkan pada anak sejak usia dini, remaja, bahkan dewasa, sehingga dapat membentuk karakter seseorang menjaadi lebih bernilai dan juga bermoral. Individu yang berkarakter baik merupakan orang yang selalu berusaha untuk melakukan berbagai hal yang terbaik terhadap Tuhan YME, dirinya sendiri, lingkungannya, orang lain, bangsa dan negaranya. Karakter yang baik berarti individu yang mengetahui tentang potensinya sendiri.

Pendidikan adalah suatu upaya sadar untuk mengembangkan potensi peserta didik secara optimal. Usaha sadar itu tidak boleh dilepaskan dari lingkungan peserta didik berada, terutama dari lingkungan budayanya, karena peserta didik hidup tak terpisahkan dalam lingkungannya dan bertindak sesuai dengan kaidah-kaidah budayanya, sehingga terbentuk kecintaan terhadap budaya bangsa sendiri.

\section{Hakikat Pendidikan Karakter}

Secara Etimologi "character" berasal dari bahasa Latin berarti instrument of narking, dari bahasa Prancis "charessein" berarti to engrove (mengukir), kemudian dari bahasa jawa "watek" berarti ciri wanci, dan dari bahasa indonesia "watak" berarti sifat pembawaan yang mempengaruhi tingkah laku, budi pekerti, tabiat, perangai.

Karakter adalah cara berpikir dan berperilaku yang menjadi ciri khas tiap individu untuk hidup dan bekerjasama, baik dalam lingkup keluarga, masyarakat, bangsa dan negara. Individu yang berkarakter baik adalah individu yang bisa membuat keputusan dan siap mempertanggungjawabkan tiap akibat dari keputusan yang ia buat.

Pendidikan adalah proses internalisasi budaya ke dalam diri seseorang dan masyarakat sehingga membuat orang dan masyarakat menjadi beradab. Pendidikan bukan merupakan sarana transfer ilmu pengetahuan saja, tetapi lebih luas 
lagi yakni sebagai sarana pembudayaan dan penyaluran nilai (enkulturasi dan sosialisasi). Seorang anak harus mendapatkan pendidikan yang menyentuh 3 dimensi dasar kemanusiaan: (1) afektif yang tercermin pada kualitas keimanan, ketaqwaan, akhlak mulia, (2) kognitif yang tercermin pada daya intelektualitas untuk menggali dan mengembangkan

kemampuannya , dan

psikomotorik yang tercermin pada kemampuan mengembangkan keterampilan teknis, kecakapan praktis, dan kompetensi kinestetis.

Menurut Suyanto (2010) karakter adalah cara berfikir dan berperilaku yang menjadi ciri khas tiap individu untuk hidup dan bekerjasama, baik dalam lingkup keluarga, masyarakat, bangsa dan Negara.

Pendidikan karakter dalam

Puskur

adalah sebagai pendidikan nilai, pendidikan budi pekerti, pendidikan moral, pendidikan watak yang bertujuan mengembangkan kemampuan siswa untuk memberikan keputusan baik-buruk, memelihara apa yang baik dan mewujudkan kebaikan itu dalam kehidupan sehari-hari dengan sepenuh hati. Demarco (tt) mengemukakan character education is the deliberate effort to help people understand, care about and act upon core ethical values.

Pendidikan karakter pada intinya bertujuan membentuk bangsa yang tangguh, kompetitif, berakhlak mulia, bermoral, bertoleran, bergotong royong, berjiwa patriotik, berkembang dinamis, berorientasi ilmu pengetahuan dan teknologi yang semuanya dijiwai oleh iman dan takwa kepada Tuhan yang Maha

Esa berdasarkan Pancasila.

Pendidikan karakter berfungsi

(1) mengembangkan potensi dasar agar berhati baik, berpikiran baik, dan berperilaku baik; (2) memperkuat dan membangun perilaku bangsa yang multikultur; (3) meningkatkan peradaban bangsa yang kompetitif dalam pergaulan dunia. Pendidikan karakter dilakukan melalui berbagai media yang mencakup keluarga, satuan pendidikan, masyarakat sipil, masyarakat politik, pemerintah, dunia usaha, dan media massa.

Atas dasar itu, pendidikan karakter bukan sekedar mengajarkan mana yang benar dan mana yang salah, lebih dari itu, pendidikan karakter menanamkan kebiasaan (habituation) tentang hal mana yang baik sehingga siswa menjadi paham (kognitif) tentang mana yang benar dan salah, mampu merasakan (afektif) nilai yang baik dan biasa melakukannya (psikomotor). Dengan kata lain, pendidikan karakter yang baik harus melibatkan bukan saja aspek "pengetahuan yang baik (moral knowing), akan tetapi juga "merasakan dengan baik atau loving good (moral feeling), dan perilaku yang baik (moral action). Pendidikan karakter menekankan pada habit atau kebiasaan yang terus-menerus dipraktikkan dan dilakukan.

\section{Cara Membangun Karakter} Anak

Karakter akan terbentuk
sebagai hasil pemahaman 3 hubungan yang pasti dialami setiap manusia (triangle relationship), yaitu hubungan dengan diri sendiri (intrapersonal), dengan lingkungan (hubungan sosial dan alam sekitar), dan hubungan dengan Tuhan YME 
(spiritual). Setiap hasil hubungan tersebut akan memberikan pemaknaan/pemahaman yang pada akhirnya menjadi nilai dan keyakinan anak. Cara anak memahami bentuk hubungan tersebut akan menentukan cara anak memperlakukan dunianya. Pemahaman negatif akan berimbas pada perlakuan yang negatif dan pemahaman yang positif akan memperlakukan dunianya dengan positif. Untuk itu, Tumbuhkan pemahaman positif pada diri anak, salah satunya dengan cara memberikan kepercayaan pada anak untuk mengambil keputusan untuk dirinya sendiri, membantu anak mengarahkan potensinya dengan begitu mereka lebih mampu untuk bereksplorasi dengan sendirinya, tidak menekannya baik secara langsung atau secara halus, dan seterusnya. Biasakan anak bersosialisasi dan berinteraksi dengan lingkungan sekitar. Ingat pilihan terhadap lingkungan sangat menentukan pembentukan karakter anak. Seperti kata pepatah bergaul dengan penjual minyak wangi akan ikut wangi, bergaul dengan penjual ikan akan ikut amis. Seperti itulah, lingkungan baik dan sehat akan menumbuhkan karakter sehat dan baik, begitu pula sebaliknya. Dan yang tidak bisa diabaikan adalah membangun hubungan spiritual dengan Tuhan Yang Maha Esa. Hubungan spiritual dengan Tuhan YME terbangun melalui pelaksanaan dan penghayatan ibadah ritual yang terimplementasi pada kehidupan sosial.

\section{Pentingnya Pendidikan Karakter pada Anak Usia SD}

Karakter yang berkualitas perlu dibentuk dan dibina sejak usia dini. Usia dini, khususnya usia SD merupakan masa kritis bagi pembentukan karakter seseorang, penanaman moral melalui pendidikan karakter sedini mengkin kepada anak-anak adalah kunci utama membangun bangsa. Karakter di sini adalah watak, tabiat, akhlak, atau kepribadian seseorang yang terbentuk dari hasil internalisasi berbagai kebajikan yang diyakini dan digunakan sebagai landasan untuk cara pandang, bepikir, bersikap dan bertindak. Kebajikan tersebut berupa sejumlah nilai moral, dan norma, seperti jujur, berani bertindak, dapat dipercaya, hormat pada orang lain, disiplin, mandiri, kerja keras, kreatif.

Pendidikan karakter di nilai sangat penting untuk ditanamkan pada anak-anak usia SD karena pendidikan karakter adalah proses pendidikan yang ditujukan untuk mengembangkan nilai, sikap, dan perilaku yang memancarkan akhlak mulia atau budi pekerti luhur. Nilainilai positif dan yang seharusnya dimiliki seseorang menurut ajaran budi pekerti yang luhur adalah amal saleh, amanah, antisipatif, baik sangka, bekerja keras, beradab, berani berbuat benar, berani memikul resiko, berdisiplin, berhati lapang, berhati lembut, beriman dan bertaqwa, berinisiatif, berkemauan keras, berkepribadian, berpikiran jauh ke depan, bersahaja, bersemangat, bersifat konstruktif, bersyukur, bertanggung jawab, bertenggang rasa, bijaksana, cerdas, cermat, demokratis, dinamis, efisien, empati, gigih, hemat, ikhlas, jujur, kesatria, komitmen, kooperatif, kosmopolitan (mendunia), kreatif, kukuh hati, lugas, mandiri, manusiawi, mawas diri, mencintai ilmu, menghargai karya orang lain, menghargai kesehatan, menghargai 
pendapat orang lain, menghargai waktu, patriotik, pemaaf, pemurah, pengabdian, berpengendalian diri, produktif, rajin, ramah, rasa indah, rasa kasih sayang,rasa keterikatan, rasa malu, rasa memiliki, rasa percaya diri, rela berkorban, rendah hati, sabar, semangat kebersamaan, setia, siap mental, sikap adil, sikap hormat, sikap nalar, sikap tertib, sopan santun, sportif, susila, taat asas, takut bersalah, tangguh, tawakal, tegar, tegas, tekun, tepat janji, terbuka, ulet, dan sejenisnya. Pada usia kanak-kanak atau yang biasa disebut para ahli psikologi sebagai usia emas (golden age) terbukti sangat menentukan kemampuan anak dalam mengembangkan potensinya. Hasil penelitian menunjukkan bahwa sekitar 50 persen variabilitas kecerdasan orang dewasa sudah terjadi ketika anak berusia empat tahun. Peningkatan 30 persen berikutnya terjadi pada usia delapan tahun, dan 20 persen sisanya pada pertengahan atau akhir dasawarsa kedua. Dari sini, sudah sepatutnya pendidikan karakter dimulai dari dalam keluarga, yang merupakan lingkungan pertama bagi pertumbuhan karakter anak. Setelah keluarga, di dunia pendidikan karakter ini sudah harus menjadi ajaran wajib sejak sekolah dasar. Anak SD masih dalam tahap perkembangan operasional konkret. Tahap dimana mulai berkembangnya kecerdasan mereka untuk berpikir logis dan sistematis. Sehingga pendidikan karakter pada anak SD menjadi kunci dalam perubahan generasi muda yang lebih baik. Nilai-nilai budi pekerti dan karakter harus diajarkan oleh para guru disekolah dasar secara baik dan benar, agar nantinya anak-anak SD bisa memiliki jiwa dan kepribadian yang unggul. Jika anak-anak SD memiliki karakter yang baik, maka besar kemungkinan Indonesia akan memiliki generasi muda yang unggul dan bermartabat nantinya. Jadi pendidikan karakter di sekolah dasar menjadi faktor utama untuk membangun karakter generasi muda menjadi lebih baik.

\section{Peran Keluarga Dalam}

\section{Pembentukan Karakter Anak}

Keluarga adalah faktor penting dalam pendidikan seorang anak. Karakter seorang anak berasal dari keluarga. Dimana sebagian sampai usia 18 tahun anak-anak di Indonesia menghabiskan waktunya 60-80 \% bersama keluarga. Sampai usia 18 tahun, mereka masih membutuhkan orangtua dan kehangatan dalam keluarga. Sukses seorang anak tidak lepas dari "kehangatan dalam keluarga".

Perkembangan otak di masa anak-anak berjalan sangat efektif. Pada masa ini bakat serta potensi akademis dan nonakademis anak bermunculan dan sangat potensial. Usia anak dari umur satu sampai tiga tahun adalah masa paling penting bagi tumbuh kembang mereka. Indikator tumbuh kembang anak tidak hanya diukur dari pertumbuhan fisik, namun juga perkembangan otak yang dapat dilihat dari responnya terhadap lingkungan. Untuk melihat kecerdasan otak seorang anak, orang tua perlu memahami perubahan apa saja yang penting bagi anak. Jika orang tua tidak tanggap dengan perkembangan anak, masalah akan datang saat anak sudah dewasa nanti.

Karakter seorang anak terbentuk terutama pada saat anak berusia 3 hingga 10 tahun. Adalah tugas kita sebagai orang tua untuk 
menentukan input seperti apa yang masuk ke dalam pikirannya, sehingga bisa membentuk karakter anak yang berkualitas. Karakter adalah sesuatu yang dibentuk, dikonstruksi, seiring dengan berjalannya waktu dan semakin berkembangnya seorang anak.

\section{Hambatan-hambatan Dalam Pembentukan Karakter Anak}

Memahami karakter anak memang terkadang begitu sulit bahkan kita seringkali tidak mampu melakukannya. Kebanyakan kita bahkan dibuat bingung oleh anak sehingga mereka merasa enggan membagi banyak hal misalnya cerita di sekolah, masalah mereka, hingga cerita-cerita yang biasa kepada kita sebagai orang tua. Ketika anak mulai tidak nyaman berbicara dengan kita, mungkin itu berarti kita belum mampu mendapatkan kepercayaan dan memahami karakter anak itu sendiri. Ada 3 kebutuhan yang harus dipenuhi pada anak usia $0-7$ tahun bahkan lebih, yaitu, (1)Kebutuhan akan rasa aman , (2) Kebutuhan untuk mengontrol (3) Kebutuhan untuk diterima. Tiga kebutuhan dasar emosi tersebut harus terpenuhi agar anak kita menjadi pribadi yang handal dan memiliki karakter yang kuat menghadapi hidup. Inilah karakter anak yang bermasalah, cukup kita melihat dari perilakunya yang nampak maka kita sudah dapat melakukan deteksi dini terhadap "musibah besar" dikehidupan yang akan datang atau dewasa. Dalam memahami karakter anak kita kan menemukan berbagai macam kendala seperti misalnya :

1. Susah diatur dan diajak kerja sama.
Hal yang paling nampak adalah anak akan membangkang, akan semaunya sendiri, mulai mengatur tidak mau ini dan itu. pada fase ini anak sangat ingin memegang kontrol. Mulai ada "pemberontakan" dari dalam dirinya. Hal yang dapat kita lakukan adalah memahaminya dan kita sebaiknya menanggapinya dengan kondisi emosi yang tenang.

2. Kurang terbuka pada pada orang tua.

Saat orang tua bertanya "Gimana sekolahnya?" anak menjawab "biasa saja", menjawab dengan malas, namun anehnya pada temannya dia begitu terbuka. Aneh bukan? Ini adalah ciri ke 2, nah pada saat ini dapat dikatakan figure orangtua tergantikan dengan pihak lain (teman ataupun ketua gang, pacar, dll). Saat ini terjadi kita sebagai orangtua hendaknya mawas diri dan mulai menganti pendekatan kita.

3. Menanggapi negatif.

Saat anak mulai sering berkomentar "Biarin aja dia memang jelek kok", tanda harga diri anak yang terluka. Harga diri yang rendah, salah satu cara untuk naik ke tempat yang lebih tinggi adalah mencari pijakan, sama saat harga diri kita rendah maka cara paling mudah untuk menaikkan harga diri kita adalah dengan mencela orang lain. Dan anak pun sudah terlatih melakukan itu, berhati-hatilah terhadap hal ini. Harga diri adalah kunci sukses di masa depan anak.

7. Upaya-upaya Yang Dilakukan Orang Tua dalam Pendidikan Karakter Anak

Ada beberapa hal yang perlu dilakukan oleh orang tua supaya anak tidak merasa enggan dengan orang tuanya sendiri. 
1. Mendengarkan anak anda dengan baik

Jangan mendengarkan anak sebagai syarat saja, namun dengarkan dengan baik, berikan respon, dan pikirkan penyelesaiannya jika anak mempunyai masalah. Banyak orang tua yang menganggap cerita anak mereka tidak penting dan hanya mendengarkan sebagai symbol atau syarat saja. Sementara itu, anak mengetahui bahwa mereka tidak didengarkan dan mulai menjauh dari orang tua. Ketika hal ini terjadi, maka orang tua sudah mengambil langkah salah untuk memahami seorang anak.

2. Berusaha memahami tipe emosional anak

Misalkan, anak anda merupakan anak yang tidak sabaran, namun sebenarnya ia bisa lebih sabar apabila diberi pengertian dengan baik. Oleh karena itu, pahami tipe emosional anak dan jangan berikan amarah atau tindak kekerasan ketika anak telah menyentuh sisi negatif dari emosinya. Berikan ia pengertian atau cari cara lain agar emosi anak tidak bertambah buruk dari waktu ke waktu.

3. Interogasi anak dengan baik

Beberapa orang tua cenderung buru-buru dan tidak sabaran ketika mereka menemukan suatu kejanggalan dan ingin mendapatkan fakta mengenai hal tersebut dari anak. jika anda melakukan interogasi dengan konsep berkata keras, memaksa, dan bahkan memukul. Maka anak akan berbohong kepada anda, serta konsep memahami karakter anak bisa pupus. Interogasi anak dengan lembut, buat ia mengatakan hal yang sebenarnya, dan ketahui bagaimana anak tersebut mampu menceritakan hal-hal yang sangat rahasia kepada anda. jika hal itu terjadi, maka anda telah memahami karakter anak dan siap untuk mendidiknya menjadi lebih baik

\section{KESIMPULAN}

Kunci utama keberhasilan dalam membangun karakter positif pada anak adalah keteladanan dimana orang tua harus menjadi orang yang memiliki karakter positif. Perbuatan dan amal baik ini bukan hanya menjadi contoh nyata bagi anak tentang bagaimana karakter positif terwujudkan dalam segala sikap, perkataan dan perbuatan kita, tetapi juga menjadi penyemangat sekaligus untuk memudahkan anak kita dalam proses tumbuh kembangnya.

Pembentukan karakter adalah sebuah perjalanan panjang dalam mendidik anak, hasilnya mungkin baru dapat kita lihat setelah proses berbulan-bulan atau bahkan bertahun-tahun. Tidak pernah ada satu 'resep' mujarab yang dapat menjawab semua permasalahan dalam menanamkan karakter positif pada anak. Kesediaan untuk selalu belajar dan memperbaiki diri yang didasari kesadaran untuk menjadi teladan dan contoh yang baik bagi anak-anak kita adalah kunci keberhasilannya. Semoga kita selalu diberi kesabaran dan kemudahan untuk terus berjuang mendidik generasi mendatang untuk menjadi manusia yang berkualitas dan berkarakter mulia.

\section{DAFTAR PUSTAKA}

Administrator. 2013. Pentingnya Pendidikan Karakter pada Anak (Online),

(http://sdnegerimoro.blogspot.com /2013/11/pentingnya-pendidikankarakter-pada.html), 
Pusat Kurikulum (Puskur). 2010.

Grand Design Pendidikan

Karakter. Jakarta: Kemdiknas:

Sardiman, AM. 2013. Pendidikan

Karakter dan Peran Pemerintah.

(Online),

(http://www.infodiknas.com/pendi

dikan-karakter-dan-peran-

pemerintah.html),

Suyanto. 2010. Urgensi Pendidikan

Karakter, (online),

(http://mendikdasmen.

kemdiknas.go.id/web/pages/urgen

si.html, 